\title{
Synthesis and Characterization of a Novel Titanium Nanoparticals using Banana Peel Extract and Investigate its Antibacterial and Insecticidal Activity
}

\author{
Rasha Sattam Hameed* (D), Raghad J. Fayyad, Rasha Saad Nuaman, \\ Noor T. Hamdan and Sara A.J. Maliki \\ Biology Department, College of Science, Mustansiriyah University, Iraq.
}

\begin{abstract}
Titanium nanoparticles (TiNPs) have been synthesized due to its certain characteristics that are expected like non-toxic, eco-friendly, and bioactivity. In this study, the researchers used Banana Peels Extract (BPE) with titanium dioxide to prepare new nanoparticles which are never carried before. These nanoparticles were biologically synthesized using an aqueous solution of banana peel extract as a bioreductant. The novel TiNPs were successfully prepared and characterized using Ultraviolet-Visible Spectroscopy (UV-VIS), Atomic Force Microscopy (AFM), X-Ray Diffractometer (XRD), and examined its antimicrobial activity against several pathogenic bacteria as well as insecticidal agent against Musca domestica. The instrumental analysis confirms the presence of TiNPs with average diameter: $88.45 \mathrm{~nm}$ and volume $31.5 \mathrm{~nm}$ as resulted by AFM and XRD respectively, while the bioactivity exam to TiNPs shows inhibitory effect against several pathogenic bacteria, as well as it cause a high mortality percentage against three larval stages of house fly.

Keywords: Banana Peel Extract (BPE), eco-friendly, titanium nanoparticals, Musca domestica.
\end{abstract}

*Correspondence: rasha.ha@yahoo.com

(Received: 18 August 2019; accepted: 12 November 2019)

Citation: Rasha Sattam Hameed, Raghad J. Fayyad, Rasha Saad Nuaman, Noor T. Hamdan and Sara A.J. Maliki, Synthesis and Characterization of a Novel Titanium Nanoparticals using Banana Peel Extract and Investigate its Antibacterial and Insecticida Activity, J Pure Appl Microbiol., 2019; 13(4):2241-2249. https://doi.org/10.22207/JPAM.13.4.38

(c) The Author(s) 2019. Open Access. This article is distributed under the terms of the Creative Commons Attribution 4.0 International License which permits unrestricted use, sharing, distribution, and reproduction in any medium, provided you give appropriate credit to the original author(s) and the source, provide a link to the Creative Commons license, and indicate if changes were made. 


\section{INTRODUCTION}

Green synthesis of nanoparticles seeks to minimize generated wastes and apply prospective progression $^{1,2}$. In latest years, materials with nano-sized aspect have paying an attention to the researchers all the way through the world. In up to date nano science and technology, the interface between inorganic nanoparticles and biological structures are one of the majority exciting area of research. In addition to that another thing is concern in this field of study like health, environmental (eco-friendly), non-toxic materials in synthesis procedures ${ }^{3,4}$.

Besides that, biosynthesis of nanoparticles has other properties like optical, catalytic, and magnetic properties which allow them to be applied in biosensing, catalysis, imaging, drug delivery, and in medicine and since it has this wide applications the production of nanoparticles is a significant aspect of nanotechnology $y^{5,6}$.

Plants, enzymes, and microorganisms were suggested to be used as probable natural alternatives products to the lethal chemicals that are non-biodegradable, hazardous to all living creatures on the earth, as well as its high cost ${ }^{7}$. Plants extracts serve as capping and reducing agents in the preparation of nanoparticles which are more beneficial comparing with other biological procedures ${ }^{8}$ these techniques of nanoparticles synthesis which based on plants are favored due to its properties as, ecofriendly, costeffective, a single-step biosynthesis process and non-toxic to workers and researchers ${ }^{9}$. Classically, different parts of the plant can be used as the main source to obtain the extract such as, fruit, fruit peels, bark, callus, and root. These parts have been examined in the synthesis of gold, silver, titanium nanoparticles in various shapes and sizes ${ }^{10}$.

Banana (Musa paradaisica), belongs to the Musaceae family, and it is a standout amongst the most vital tropical fruits in the world market and usually after pulp consumption, banana peels are usually discarded, the peels represent approximately $18-33 \%$ of the whole fruit, and presently peels are not used for any other purposes and sometimes it is used as animals food in a very limited extent ${ }^{11}$. It is therefore a significant and vital to discover applications for these peels in ecological topics. It was found that banana peels are rich in pectin, lignin and hemicelluloses which encourage the researchers in current study to use them in green synthesis of nanoparticles, furthermore, banana peels contains large amounts of phenolic compounds that can act as a ligand and coordinate with the metal ion and form the metallic nanoparticles ${ }^{12}$.

Titanium dioxide $\left(\mathrm{TiO}_{2}\right)$ is naturally formed and usually used as a white pigment and paints, food colorants, papers, plastics, inks, and toothpastes because it is nontoxic, it is also considered as low-cost metal due to its wide existence in nature. Due to its ability to absorb UV light and high refractive index, $\mathrm{TiO}_{2}$ nanoparticles have been used to synthesize nanoparticles with many plants like Nyctan, arbortristis extract, leaf extract of Catharanthus roseus, Eclipta prostrate aqueous leaf extract, and peel extract of Annona squamosa $L^{13,14}$.

In the current paper, titanium dioxide has been used for the first time with the water extract obtained from banana peels to synthesize the titanium nanoparticles TiNPs and was characterized using several instrumental analysis (UV-visible spectroscopy, XRD and AFM). Activity of nove TiNPs against bacteria and insecticide agents as well as against several pathogenic bacteria and (Muscadomestica) respectively has been examined and discussed.

\section{MATERIALS AND METHODS \\ Preparation of Banana Peel Extract (BPE)}

Fresh banana was gained from local markets; banana peels were cut it into small pieces, washed three times with distilled water to remove external dirt layers and contaminants from it then, the peels pieces were dried on paper toweling. A $75 \mathrm{~g}$ of peels were place in a beaker containing $150 \mathrm{ml}$ double distilled water and then boiled at $100^{\circ} \mathrm{C}$ for $20 \mathrm{~min}$, and filtered through Whatman No. 1 filter paper for two times. The extract was stored in fridge at $4^{\circ} \mathrm{C}^{15}$.

\section{Preparation of titanium dioxide nanoparticles} ( $\left.\mathrm{TiO}_{2} \mathrm{NPs}\right)$

Titanium dioxide was obtained from Sigma Aldrich, China. Molar mass was $79.87 \mathrm{~g} /$ mol and density was $4.2 \mathrm{~g} / \mathrm{cm}^{3}$. Their average size of the titanium oxide bulk particles ( $\mathrm{TiO}_{2} \mathrm{BPs}$ ) was $(550 \mathrm{~nm})$. Deionized distilled water (DW) was used as a solvent to prepare a solution of $(100 \mathrm{mg} / \mathrm{ml})$ concentration, and then only $5 \mathrm{ml}$ of this solution 
was added in dropwise to $50 \mathrm{ml}$ of Banana Peel Extract (BPE) solution with a continuance stirring (300 rpm) for one hour, this mixing process was a achieved on a hot plate using magnetic stirrer and at ambient temperature.

Characterization of $\mathrm{TiO}_{2}$ nanoparticles

UV-visible Spectroscopy

The UV-VIS absorption spectra of novel

TiNPs solution was achieved using Schimadzu 1601 spectrophotometer and 200-800 nm range ${ }^{16}$.

\section{Atomic Force Microscopy (AFM)}

This analysis was used to characterize many properties of biosynthesized NPs such as, NPs size, NPs surface, NPs topography, and granularity volume distribution of NPs. A thin film of the NPs sample was prepared on a glass slide using $100 \mu \mathrm{l}$ of the sample on the slide, allowed to dry for $5 \mathrm{~min}$, then the slide was scanned using AFM, (AA-3000, USA) ${ }^{17}$.

\section{$X$-Ray Diffraction}

X-Ray Diffractometer (XRD) was used to determine and identify the formation of the synthesized NPs, the XRD apparatus (Shimadzu 6000 , Japan) operate at a voltage of (40 kv) and current of $(30 \mathrm{mM})$ with $\mathrm{Cu} K \alpha$ radiation in a $(\theta-2 \theta)$ configuration.

\section{Microorganisms}

Microorganisms were collected from laboratory of post graduate in biology department / College of Science / AL-Mustansireyah University. These micro-organisms are: Gram-positive bacteria (Bacillus sp., Staphylococcus aureus, Staphylococcus epidermidis, Streptococcus sp.) and Gram-negative bacteria (Pseudomonas aeruginosa, Escherichia coli, Kleipseilla sp.,) the strains of bacteria were maintained on nutrient agar slants at $4^{\circ} \mathrm{C}$.

Antibacterial activity of synthesized NPs and banana peel extract (BPE)

Three concentrations of $\mathrm{TiO}_{2} \mathrm{NPs}$ were prepared in $(100,50$, and $25 \mathrm{mg} / \mathrm{ml}) \mathrm{m}$ there bioactivity were evaluated using well diffusion method according to $(\mathrm{CLSI})^{18}$.

\section{Insects rearing and Larvicidal bioassay}

The Insects colony was collected from house fly (Musca domistica) which is free from insecticides and pathogenic organisms, this animal house belong to Biology Department, College of Science, Al-Mustansiriyah University. The colony was maintained under $28 \pm 2{ }^{\circ} \mathrm{C}$ (starting from $1^{\text {st }}$ larval stage reaching to $3^{\text {rd }}$ instar stage). The $1^{\text {st }}$, $2^{\text {nd }}$, and $3^{\text {rd }}$ instar larvae were completed in healthy environment; each test was replicated for three times. The collected Musca domistica larvae were placed in a cup contains $10 \mathrm{~g}$ of nutritional media (this media consist of $10 \mathrm{~g}$ of yeast extract, $200 \mathrm{~g}$ of fish food, and $100 \mathrm{ml}$ of distilled water). $2 \mathrm{~mL}$ from each concentration of $\mathrm{TiO}_{2} \mathrm{NPs}$ were added to each cup; all cups were covered with muslin cloth and kept in room temperature for $24 \mathrm{hrs}$. Larvae were considered dead if there is no significant motility ${ }^{19}$, mortality percentage was calculated by applying Abbott's formula ${ }^{20}$ :

$\frac{X-Y}{X} \times 100=$ Percent of corrected control

$X$ : Percent of alive in the check

$Y$ : Percent of alive in the treatment

\section{RESULTS AND DISCUSSION}

Identification of $\mathrm{TiO}_{2}$ nanoparticals

Titanium nanoparticles were identified via different considerations, visually the reaction mixture of TiNPs turned to white grayish color after 30 min. comparing with the white color of titanium oxide indicating the formation of titanium nanoparticles as shown in Fig. 1.

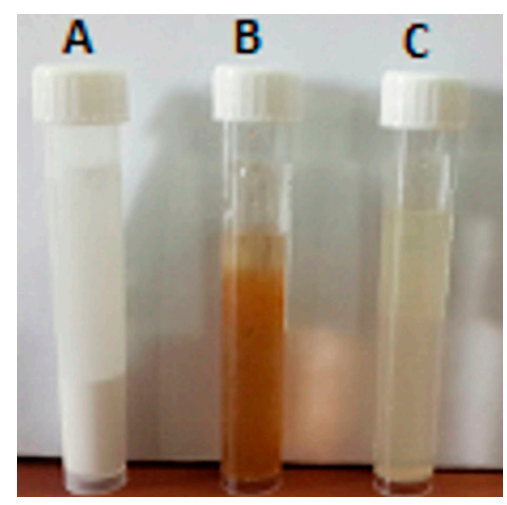

Fig. 1. Shows the comparison between three solutions: A: Titanium Dioxide bulk solution

B: Water extract of banana peel solution

C: Titanium Dioxide nanoparticles solution

Table 1. Dimensions of synthesized $\mathrm{TiO}_{2}$ NPs

\begin{tabular}{lc}
\hline Roughness average & $1.53 \mathrm{~nm}$ \\
Root mean square & $1.77 \mathrm{~nm}$ \\
Average diameter & $88.45 \mathrm{~nm}$
\end{tabular}




\section{UV-Visible Spectral}

Fig. 2 represent the TiNPs UV-Visible spectra, the $\mathrm{TiO}_{2}$ absorbance was 4.2 at wave length $208 \mathrm{~nm}$, while Fig. 3 shows the value of energy gap (Eg) of TiNPs which was 4.7(ev) these results are agreed with Jawad $2017^{21}$.

\section{Atomic Force Microscopy (AFM)}

Table 1 indicates the size of TiNPs ranged between (65-115 $\mathrm{nm}$ ) with average diameter $(88.45 \mathrm{~nm})$, while the roughness average (RA) and root mean square were $1.53 \mathrm{~nm}$ and $1.77 \mathrm{~nm}$ respectively. Fig. 4 shows AFM topographic images of the TiNPs while Fig. 5 shows granularity volume distribution of TiNPs.

\section{X-Ray Diffraction (XRD)}

Fig. 6 shows the X-Ray Diffractometer pattern, the diagram indicates the presence of three peaks, strong diffraction peaks (2-theta $\left.28.2956^{\circ}\right),\left(2\right.$-theta $\left.40.4901^{\circ}\right)$, and (2-theta $50.1821^{\circ}$ ), while the average crystallite size of TiNPs was $31.5 \mathrm{~nm}$ according to Scherer's equation.

Antimicrobial activity of titanium nanoparticles Bioactivity of the novel TiNPs showed that these nanoparticals exhibited antimicrobial impact against the pathogenic microorganisms, the

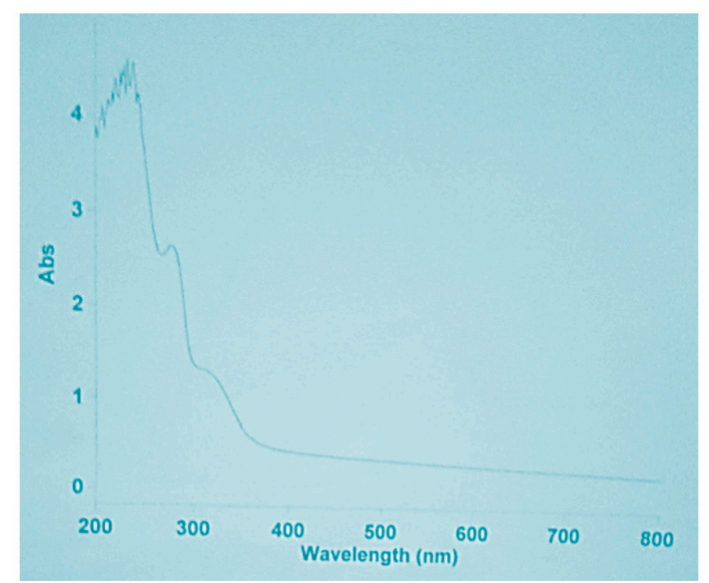

Fig. 2. Absorbance spectrum of synthesized ( $\left.\mathrm{TiO}_{2} \mathrm{NPs}\right)$

inhibition zone diameter was varies as depicted in Table 2, while Banana Peels Extract (BPE) did not shows any activity against these bacteria.

All the prepared concentrations of titanium nanoparticals shows bioactivity against the gram positive bacteria (Stapylococcus aureus), and (Steptococcus spp.) while the first concentration (25\%) doesn't shows any activity against (Staphylococcus Epidermidis, Escherecia. coli, Klebsiella spp., and Bacillu ssp.) as it is clearly

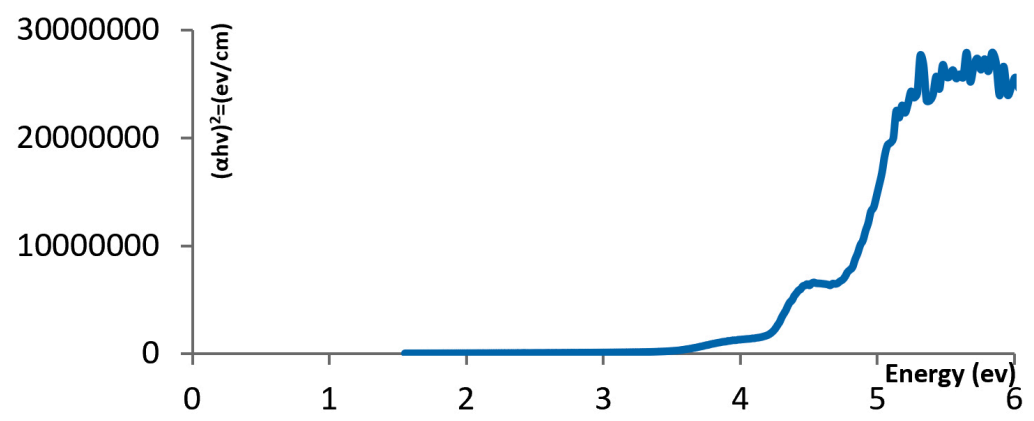

Fig. 3. Energy gap diagram for $\left(\mathrm{TiO}_{2} \mathrm{NPs}\right)$ thin film

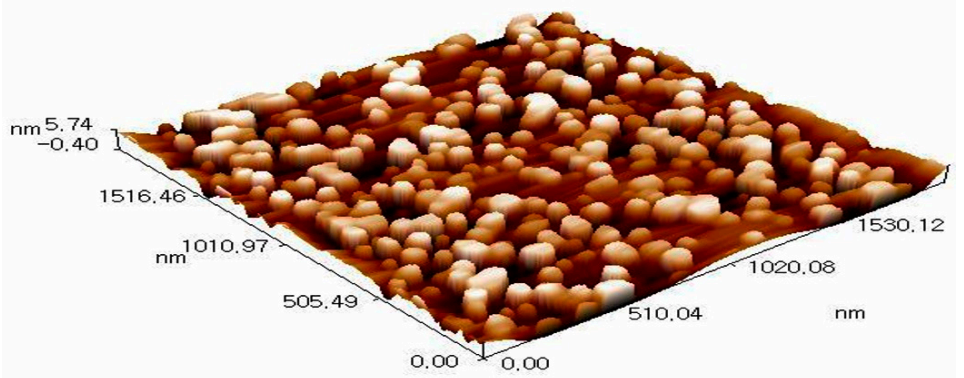

Fig. 4. AFM topographic images 
appear from Table 2. Also the results show that there was no antimicrobial activity for banana peel extract against all tested pathogens.

Table 2 indicates that best effective concentration to the newly synthesized TiNPs was on $50 \%$ conc., this concentration shows strong bioactivity against gram positive bacteria than negative bacteria, that's because Gram negative bacteria have cell walls with a thin layer of peptidoglycan and an outer membrane with a

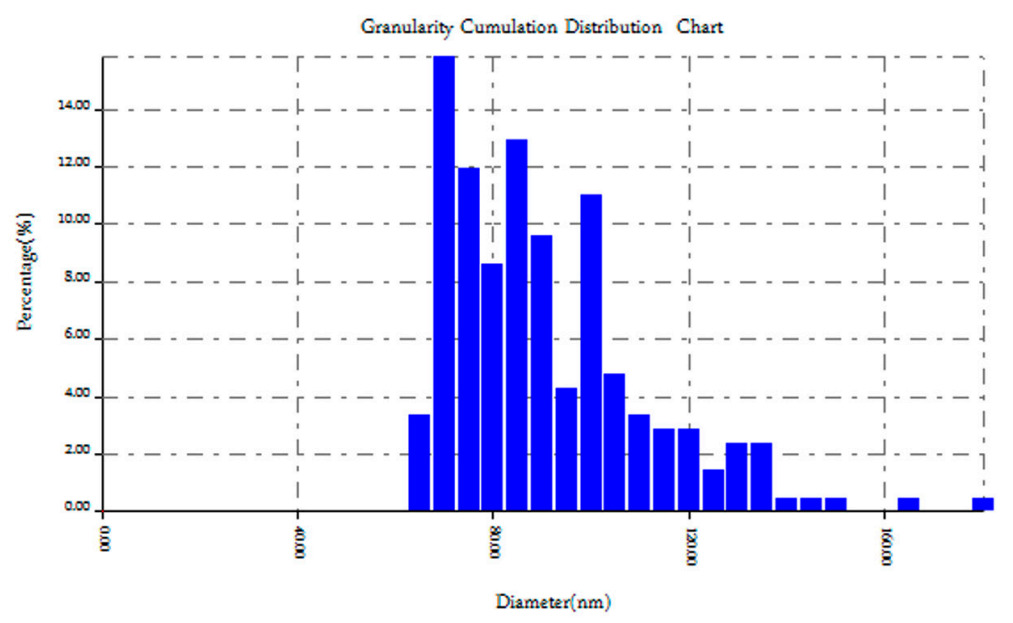

Fig. 5. Granularity volume distribution of TNPs

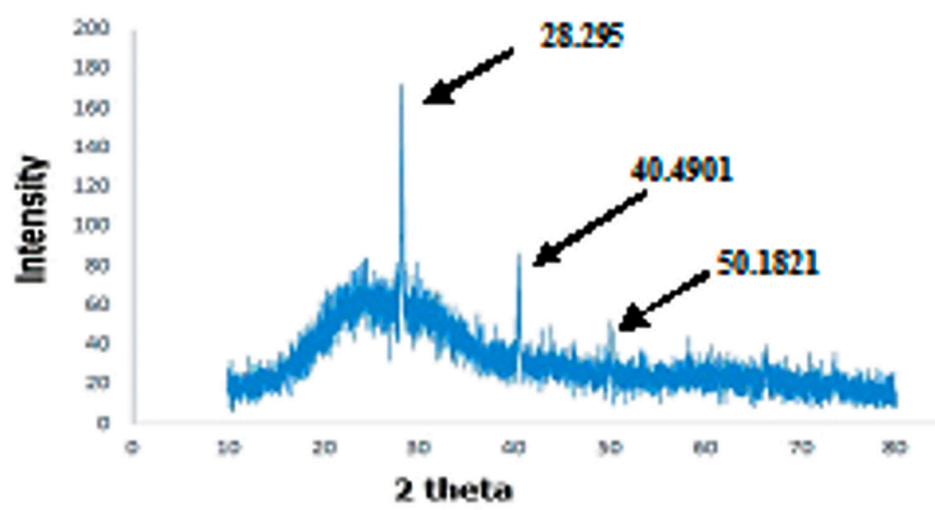

Fig. 6. X-Ray Diffractometer pattern of TiNPs

Table 2. Bioactivity of TiNPs against certain bacteria

\begin{tabular}{|c|c|c|c|c|c|c|}
\hline \multirow[t]{3}{*}{ Compound } & \multicolumn{6}{|c|}{ Pathogenic Microorganism } \\
\hline & \multicolumn{3}{|c|}{ Gram Positive } & \multicolumn{3}{|c|}{ Gram Negative } \\
\hline & $\begin{array}{c}\text { Stapylococcus } \\
\text { aureus }\end{array}$ & $\begin{array}{c}\text { Steptococcus } \\
\text { spp. }\end{array}$ & $\begin{array}{c}\text { Staphylococcus } \\
\text { Epidermidis }\end{array}$ & $\begin{array}{c}\text { Bacillus } \\
\text { Sp. }\end{array}$ & $\begin{array}{c}\text { Escherecia } \\
\text { coli }\end{array}$ & $\begin{array}{c}\text { Klebsiella } \\
\text { spp. }\end{array}$ \\
\hline \multicolumn{7}{|l|}{ Banana Peels } \\
\hline \multicolumn{7}{|l|}{ Extract (BPE) } \\
\hline TiNPs $25 \%$ conc. & 6 & 18 & & & & \\
\hline TiNPs $50 \%$ conc. & 27 & 16 & 18 & 15 & 21 & 13 \\
\hline TiNPs $100 \%$ conc. & 16 & 12 & & & & \\
\hline
\end{tabular}

5-10 week activity against bacteria, 10-15 Moderate activity, 15+ Over 15 consider to be strongly active. 
lipopolysaccharide component which is not exist or found in Gram positive bacteria and this property enable the TiNPs to penetrate the cell membrane of Gram positive bacteria and cause its fatality, this results agreed with the results obtained by Adam and his coworkers ${ }^{22}$ and Shrevastava and his coworkers ${ }^{23}$.

The most logical explanation proposed that the possible mechanisms involving the interaction between TiNPs with the biomolecules which propose that microbes have negative charge (represented by the membrane of the microbe) and the positive charge (represented by TiNPs), this "electromagnetic" attraction between the metal ion and the microbe membrane will leads to microbial oxidation and rapid death ${ }^{24}$.

Zhang and his coworkers suggested that positive ion in nanoparticals form a coordination bond with the thiol group (-SH) which is part of protein molecule which is part of bacteria membrane, this deactivation of protein will increase the permeability of the bacteria membrane leading to fast death ${ }^{25}$.

Larvicidal effect of TiNPs

Fig. 7 indicates the larvicidal analysis by which the larvae death was scored after 24 hrs, the results shows that there was a marked mortality recorded during the development of (Musca domistica) larvae depending upon the concentration of each dose. The highest mortality was observed for $1^{\text {st }}$ stage followed by $2^{\text {nd }}$ and $3^{\text {rd }}$ larval stage respectively. While insignificant mortality observed in $1^{\text {st }}$ larval stage vials treated with water and BPE $(6.6 \%, 6.6 \%)$ as shown in Fig. 8 .

The mortality percentage is proportional to the concentration of the synthesized TiNPs which indicates that the essential role of concentration in larvicidal activity. Each test included a control group with three replicates for each concentration.

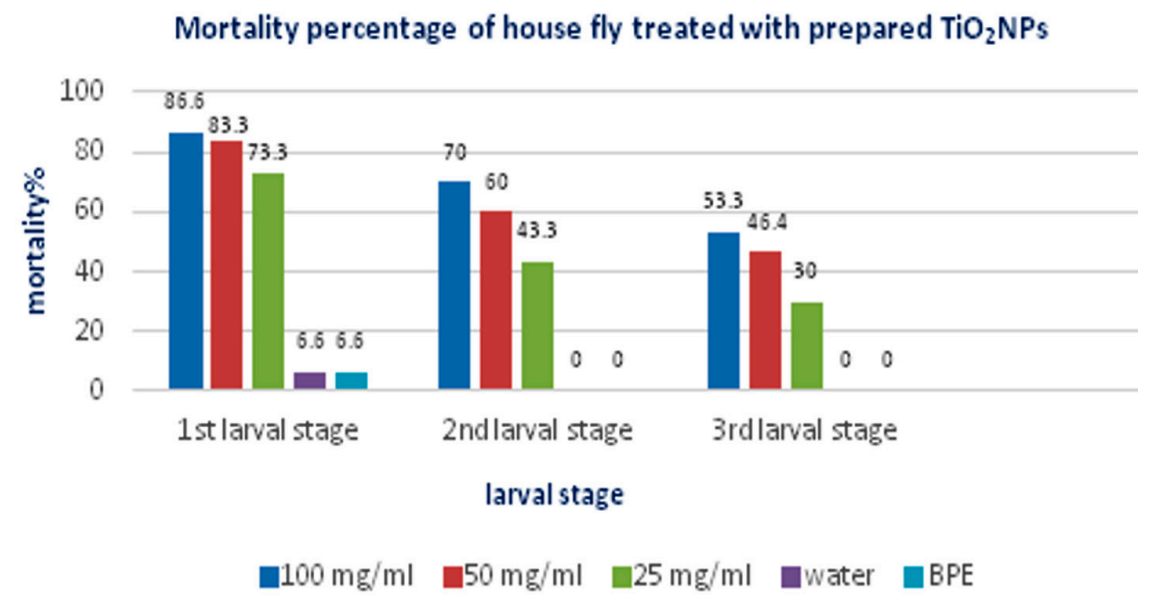

Fig. 7. Mortality percentage of house fly larvae treated with synthesized $\mathrm{TiO}_{2} \mathrm{NPs}$

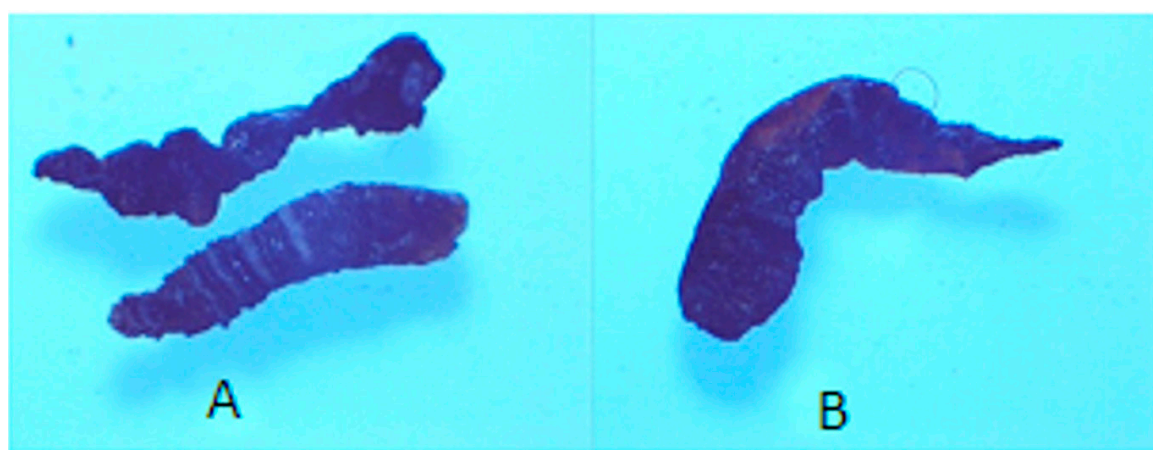

Fig. 8. Phenotypic variation observed in A: $2^{\text {nd }}$ larval stage, B: $3^{\text {rd }}$ larval stage of Musca domistica treated with 100 $\mathrm{mg} / \mathrm{ml}$ prepared TiNPs 
The results agreed with Sabat and his coworkers ${ }^{26}$. After hatching from the egg, the larva starts feeding with TiNPs treated food, once it pass in larval gut, it interferes with the a certain process that leads to unusual phenotypes which end with neuronal defect, ending with larvae death. Hassan and his coworkers ${ }^{27}$ reported that the possible mechanism behind the death of house fly is the dispersion of metal nanoparticles via oral route or through rupturing of the cuticle membrane, by this means the TiNPs enter into the cavity of insect body to affect the surviving the ability of generating the Reactive Oxygen Species (ROS), these particles are causative agent for oxidative stress, which leads to eggs damage due to its toxic tension, then the egg are not able to proceed on its next developmental stages. This analogous mechanism was recorded by magnetite NPs which shows bioactivity against Drosophilla melanogaster ${ }^{28}$ and silver NPs bioactivity against Culex pipienes ${ }^{29}$.

In producing TiNPs, there several factors affecting its yield among them are temperature of the synthesis process, $\mathrm{pH}$ of the reaction, purity of the metal salt in addition to the extract itself, these factors play an effective role on the yield and characteristics of TiNPs, these factors was studied by Njagi and his coworkers ${ }^{30}$.

In this study, the researchers used banana peels extract in a new green synthesis method to synthesized titanium nanoparticals, this method has not been carried before and it was found that TiNPs show bioactivity against bacteria which increase its future applications against many serious human pathogens. In addition, TiNPs shows good larvicidal applications against Musca domistica resulted. These results will open wide and new biomedical applications.

\section{CONCLUSION} points:

The researcher concludes the following

1. A novel, green, eco-friendly TiNPs was synthesized successfully.

2. The synthesis procedure was rapid, simple, and considered as a new approach method to synthesize $\mathrm{TiO}_{2} \mathrm{NPs}$.

3. The synthesis was based on using agricultural waste material (banana peels).
4. Banana peels were chosen in this research due to its composition (rich with pectin, cellulose, hemicelluloses...) in addition to its low cost.

5. Due to the bioactivity of the novel TiNPs against bacteria and insects (house fly), the researchers expect a wide and various applications of green synthesized nanoparticles precisely against infectious bacteria, biomedical, and pharmaceutical applications

\section{ACKNOWLEDGEMENTS}

The authors would like to thank all the staff at Biology Department, College of Science, Mustansiriyah University, Iraq for their support and help to achieve this research.

\section{CONFLICT OF INTEREST}

The authors declares that there is no conflict of interest.

\section{AUTHOR'S CONTRIBUTION}

All authors listed have made a substantial, direct and intellectual contribution to the work, and approved it for publication.

\section{FUNDING}

None.

\section{DATA AVAILABILITY}

All datasets generated or analyzed during this study are included in the manuscript and/or the Supplementary Files.

\section{ETHICS STATEMENT}

This article does not contain any studies with human participants or animals performed by any of the authors.

\section{REFERENCES}

1. Xianchun Z, Kavitha P, Huey-Min H. Green Synthesis, Characterization and Applications of Nanoparticles. Micro and Nano Technologies, Chapter 10, Elsevier, 2019; 223-263.

2. Thakur BK, Kumar A, Kumar D. Green synthesis of titanium dioxide nanoparticles using Azadirachta indica leaf extract and evaluation of their antibacterial activity. South African Journal of Botany, 2019; 124: 223-227. https://doi.org/10.1016/j.sajb.2019.05.024 Prasad K, Anal KJ, Kulkarni AR. Lactobacillus-assisted synthesis of titanium nanoparticles. Nanoscale Res 
Lett., 2007; 2(5): 248-250. https://doi.org/10.1007/ s11671-007-9060-x

4. Sudha, SS, Rajamanickam, K, Rengaramanujam, J. microalgae mediated synthesis of silver nanoparticals and their antibacterial activity against pathogenic bacteria. Indian Journal of Experimental Biology, 2013; 52: 339-399.

5. Jain PK, Huang X, El-Sayed IH, El-Sayed MA. Noble metals on the nanoscale: optical and photothermal properties and some applications in imaging, sensing, biology, and medicine. Accounts of Chemical Research, 2008; 41: 1578-1586. https://doi.org/10.1021/ ar7002804

6. Nair R, Varghese SH, Nair BG, Maekawa T, Yoshida $Y$, Kumar DS. Nanoparticulate material delivery to plants. Plant Sci., 2010; 179: 63-145. https://doi. org/10.1016/j.plantsci.2010.04.012

7. Okoth KJO. Synthesis and characterization of iron nanoparticals using banana peels extracts and their application in aptasensor. M.Sc. thesis, university of Nairobi, 2016.

8. Valli JS, Vaseeharan B. Biosynthesis of silver nanoparticles by Cissus quadrangularis extracts. Materials Letters, 2012; 82: 171-173. https://doi. org/10.1016/j.matlet.2012.05.040

9. Matteo C, Thomas RG, Christopher BM. Solution-Phase Synthesis of Titanium Dioxide Nanoparticles and Nanocrystals. Chem. Rev., 2014; 114(19): 9319-9345. https://doi.org/10.1021/cr500170p

10. Siavash I. Green synthesis of metal nanoparticles using plants. Green Chemistry, 2011; 13: 2638-2650. https:// doi.org/10.1039/c1gc15386b

11. Bankar A, Joshi B, Kumar AR, Zinjarde S. Banana peel extract mediated novel route for the synthesis of silver nanoparticles. Colloids and Surfaces A: Physicochemical and Engineering Aspects. 2010; 368(1): 58-63. https:// doi.org/10.1016/j.colsurfa.2010.07.024

12. Ratul KD, Vinayak LP, Linson L, Mitra N, Rama P. Biological synthesis of metallic nanoparticles: plants, animals and microbial aspects. Nanotechnol. Environ. Eng., 2017; 2: 18. https://doi.org/10.1007/s41204017-0029-4. https://doi.org/10.1007/s41204-0170029-4

13. Sundrarajan M, Gowri S. Green synthesis of titanium dioxide nanoparticles by Nyctanthes arbortristis leaves extract. Chalcogenide Lett., 2011; 8: 447-451.

14. Roopan SM, Bharathi A, Prabhakarn A, Rahuman AA, Velayutham K, Rajakumar G. Efficient phytosynthesis \&structural characterization of rutile $\mathrm{TiO} 2$ nanoparticles using Annona squamosa peel extract. Spectrochim Acta Part A, 2012; 98: 86-90. https://doi. org/10.1016/j.saa.2012.08.055

15. Narayanamma A. Natural Synthesis of Silver Nanoparticles by Banana Peel and As an Antibacterial Agent Extract. IOSR Journal of Polymer and Textile Engineering (IOSR-JPTE), 2016; 3(1): 17-25.

16. Ba-Abbad MM, Kadhum AH, Mohamad AB, Takriff MS, Sopian K. Synthesis and catalytic activity of $\mathrm{TiO}_{2}$ nanoparticles for photochemical oxidation of concentrated chlorophenols under direct solar radiation. International Journal of Electrochemical
Science. 2012; 7: 4871-4888.

17. Naveen HKS, Kumar G, Karthik L, Bhaskara RKV. Extracellular biosynthesis of silver nanoparticles using the filamentous fungus Penicillium sp. Archives of Applied Science Research, 2010; 2(6): 161-167.

18. Clinical and Laboratory Standards Institute (CLSI): Performance for antimicrobial Susceptibility, 2007.

19. Kumar D, Chawla R, Dhamodaram P, Balakrishnan N. Larvicidal activity of Cassia occidentalis (Linn.) against the larvae of bancroftian filariasis vector mosquito Culex quinquefasciatus. Journal of Parasitology Research, 2014; 5: 236838. https://doi. org/10.1155/2014/236838

20. Eslin P, PreVost G. Hemocyte load and immune resistance to Asobara tabida are correlated in species of the Drosophila melanogaster subgroup. Journal of Insect Physiology, 1998; 44: 807-816. https://doi. org/10.1016/S0022-1910(98)00013-4

21. Jawad MM. Green synthesis, of Mineral Oxide Nanoparticles by Some Plant Extracts and Study its Biological Effects. M.Sc. thesis. College of Science, Mustansiriyah University. 2007; 138 pp.

22. Adams KL, Lyon YD, Alvarez JJP. Comparative ecotoxicity of nanoscale $\mathrm{TiO}_{2}, \mathrm{SiO}_{2}$, and $\mathrm{ZnO}$ water suspensions. Water Res., 2006; 40(19): 3527-3532. https://doi.org/10.1016/j.watres.2006.08.004

23. Shrivastava S, Bera T, Roy A, Singh G, Ramachandrarao $P$, Dash D. Characterization of enhanced antibacterial effects of novel silver nanoparticles. Nanotechnology, 2007; 18: 103e112. https://doi.org/10.1088/09574484/18/22/225103

24. Bar H, Bhui DK, Sahoo GP, Sarkar P, Pyne S, Misra A. Green synthesis of silver nanoparticles using seed extract of Jatrophacurcas. Colloids and Surfaces A-Physicochemical and Engineering Aspects, 2009; 348: 212e216. https://doi.org/10.1016/j. colsurfa.2009.07.021

25. Zhang $\mathrm{H}$, Chen G. "Potent Antibacterial Activities of $\mathrm{Ag} / \mathrm{TiO}_{2}$ Nanocomposite Powders Synthesized by a One-Pot Sol-Gel Method," Environ. Sci. Technol., 2009; 43(8): 2905-2910. https://doi.org/10.1021/es803450f 26. Sabat D, Patnaik A, Ekka B, Dash P, Mishra M. Investigation of titania nanoparticles on behaviour and mechanosensory organ of Drosophila melanogaster. Physiology and Behavior., 2016; 167: 76-85. https:// doi.org/10.1016/j.physbeh.2016.08.032

27. Hassan SE, Salem SS, Fouda A, Awad MA, El-Gamal MS, Abdo AM. New approach for antimicrobial activity and bio-control of various pathogens by biosynthesized copper nanoparticles using endophytic actinomycetes. Journal of Radiation Research and Applied Sciences, 2018; 5(3): 1-9. https://doi. org/10.1016/j.jrras.2018.05.003

28. Chen H, Wang B, Feng W, Ouyang W, Du H, Chai, Z. Oral magnetite nanoparticles disturb the development of Drosophila melanogaster from oogenesis to adult emergence, Nanotoxicology, 2015; 9(3): 302-312. doi: 10.3109/17435390.2014.929189. https://doi.org/10. 3109/17435390.2014.929189

29. Hameed RS, Ahmed S, Nuaman RS, Fayyad RJ. Synthesis Myconanoparticles by using Metarhizium anisopliae 
Hameed et al. J Pure Appl Microbiol, 13(4), 2241-2249 | December 2019 | https://doi.org/10.22207/JPAM.13.4.38

as a biological management for Culex pipiens. International Journal of Biosciences, 2018; 12(6): 323333.

30. Njagi EC, Huang H, Stafford L, Genuino H, Galindo
HM, Collins JB, Suib SL. Biosynthesis of iron and silver nanoparticles at room temperature using aqueous sorghum bran extracts. Langmuir., 2011; 27(1): 264271. https://doi.org/10.1021/la103190n 